Research article

\title{
Altered peptide ligands inhibit arthritis induced by glucose-6-phosphate isomerase peptide
}

\author{
Keiichi Iwanami1, Isao Matsumoto1,2, Yohei Yoshiga1, Asuka Inoue1, Yuya Kondo1, \\ Kayo Yamamoto1, Yoko Tanaka1, Reiko Minami1, Taichi Hayashi ${ }^{1}$, Daisuke Goto1, Satoshi Ito1, \\ Yasuharu Nishimura ${ }^{3}$ and Takayuki Sumida ${ }^{1}$
}

\author{
1Department of Clinical Immunology, Doctoral Program in Clinical Science, Graduate School of Comprehensive Human Science, University of \\ Tsukuba, 1-1-1 Tennoudai, Tsukuba 305-8575, Japan \\ 2PRESTO, Japan Science and Technology Agency, 4-1-8 Honcho Kawaguchi, Saitama 332-0012, Japan \\ ${ }^{3}$ Department of Immunogenetics, Graduate School of Medical Sciences, Kumamoto University, 2-39-1 Kurokami, Kumamoto 860-8556, Japan \\ Corresponding author: Isao Matsumoto, ismatsu@md.tsukuba.ac.jp
}

Received: 4 May 2009 Revisions requested: 2 Jul 2009 Revisions received: 23 Sep 2009 Accepted: 9 Nov 2009 Published: 9 Nov 2009

Arthritis Research \& Therapy 2009, 11:R167 (doi:10.1186/ar2854)

This article is online at: http://arthritis-research.com/content/11/6/R167

(c) 2009 Iwanami et al.; licensee BioMed Central Ltd.

This is an open access article distributed under the terms of the Creative Commons Attribution License (http://creativecommons.org/licenses/by/2.0), which permits unrestricted use, distribution, and reproduction in any medium, provided the original work is properly cited.

\begin{abstract}
Introduction Immunosuppressants, including anti-TNF $\alpha$ antibodies, have remarkable effects in rheumatoid arthritis; however, they increase infectious events. The present study was designed to examine the effects and immunological change of action of altered peptide ligands (APLs) on glucose-6phosphate isomerase (GPI) peptide-induced arthritis.
\end{abstract}

Methods DBA/1 mice were immunized with $\mathrm{hGPI}$ 325-339, and cells of draining lymph node (DLN) were stimulated with $\mathrm{hGPI}_{325-339}$ to investigate the T-cell receptor (TCR) repertoire of antigen-specific CD4 ${ }^{+} \mathrm{T}$ cells by flow cytometry. Twenty types of APLs with one amino acid substitution at a TCR contact site of $\mathrm{hGPI}_{325-339}$ were synthesized. CD4+ $\mathrm{T}$ cells primed with human GPI and antigen-presenting cells were co-cultured with each APL and cytokine production was measured by ELISA to identify antagonistic APLs. Antagonistic APLs were co-immunized with $\mathrm{hGPI}_{325-339}$ to investigate whether arthritis could be antigenspecifically inhibited by APL. After co-immunization, DLN cells were stimulated with $\mathrm{hGPI}_{325-339}$ or APL to investigate Th17 and regulatory $\mathrm{T}$-cell population by flow cytometry, and anti-mouse GPI antibodies were measured by ELISA.

Results Human $\mathrm{GPI}_{325-339}$-specific Th17 cells showed predominant usage of TCRV $\beta 8.1$ 8.2. Among the 20 synthesized APLs, four (APL 6; N329S, APL 7; N329T, APL 12; G332A, APL 13; G332V) significantly reduced IL-17 production by $\mathrm{CD}^{+} \mathrm{T}$ cells in the presence of $\mathrm{hGPI}_{325-339}$. Coimmunization with each antagonistic APL markedly prevented the development of arthritis, especially APL 13 (G332V). Although co-immunization with APL did not affect the population of Th17 and regulatory T cells, the titers of anti-mouse GPI antibodies in mice co-immunized with APL were significantly lower than in those without APL.

Conclusions We prepared antagonistic APLs that antigenspecifically inhibited the development of experimental arthritis. Understanding the inhibitory mechanisms of APLs may pave the way for the development of novel therapies for arthritis induced by autoimmune responses to ubiquitous antigens.

\section{Introduction}

Rheumatoid arthritis (RA) is characterized by symmetrical polyarthritis and joint destruction. Although the etiology is considered autoimmune reactivity to some antigens, the exact mechanisms are not fully understood. Pathological examinations show that most of the lymphocytes infiltrating the synovium in RA are $\mathrm{CD} 4{ }^{+} \mathrm{T}$ cells, which can recognize some antigens and expand oligoclonally intraarticularly [1]. These findings imply the possible role of CD4+ T cells in the pathogenesis of RA. Previous studies showed that cytotoxic T-lymphocyte antigen-4 immunoglobulin and tacrolimus have remarkable effects on RA, and stressed the importance of $\mathrm{CD} 4{ }^{+} \mathrm{T}$ cells in the pathogenesis of RA [2-4].

Ab: antibody; APC: antigen-presenting cell; APL: altered peptide ligand; Cll: collagen type II; DLN: draining lymph node; ELISA: enzyme-linked immunosorbent assay; GPI: glucose-6-phosphate isomerase; IFN: interferon; IL: interleukin; MBP: myelin basic protein; MHC: major histocompatibility complex; PBS: phosphate-buffered saline; PLP: proteolipid protein; RA: rheumatoid arthritis; rhGPI: recombinant human glucose-6-phosphate isomerase; TCR: T-cell receptor; Th: T-helper; TNF: tumor necrosis factor. 
Although the exact helper T-cell lineage critical in RA remains elusive, previous animal studies reported that Th17 cells play a crucial role and that Th1 cells may have a protective role against the progress of arthritis in most mouse models with the exception of proteoglycan-induced arthritis in Balb/c mice [5]. Collagen-induced arthritis in the C57BL/6 background is markedly suppressed in IL-17-deficient mice [6], and glucose6-phosphate isomerase (GPI)-induced arthritis in the DBA/1 background and antigen-induced arthritis in the C57BL/6 background are also suppressed by the administration of antiIL-17 antibodies (Abs) [7,8]. In these models, complete Freund's adjuvant is used for the induction of arthritis; therefore it is possible that the components of Mycobacterium tuberculosis affect the cytokine dependency. The arthritis seen in IL-1 receptor antagonist-deficient mice in the Balb/c background and SKG mice in the Balb/c background, however, is completely suppressed in IL-17-deficient mice $[9,10]$. These findings indicate that Th17 cells play a central role in murine models independent of mouse strains and target antigens.

$\mathrm{IL}-17$ is also considered to play a crucial role in host defense. IL-17 signaling seems essential for the recruitment of neutrophils to the alveolar space in pneumonia caused by Klebsiella pneumoniae, Mycoplasma pneumoniae and Pneumocystis jiroveci [11-13]. IL-17 is also involved in mucosal host defense against oropharyngeal candidasis via salivary antimicrobial factors, in addition to neutrophil recruitment [14]. Furthermore, IL-17 production by $\gamma \delta \mathrm{T}$ cells is essential against peritonitis caused by Escherichia coli [15]. In this regard, anti-cytokine therapies such as infliximab and tocilizumab have been applied to clinical treatment and have shown striking effects on RA [16-19]; anti-IL-17 therapy could therefore be useful in the treatment of RA. Blockade of IL-17 could increase the likelihood of infections, however, and the use of such a strategy would be limited just like the case of infliximab and tocilizumab.

Altered peptide ligands (APLs) are peptides with substitutions in amino acid residues at T-cell receptor (TCR) contact sites, and can be either agonistic, antagonistic with partial activation or antagonistic [20]. These three different actions seem to depend on the site and residue of the peptide substitution [21]. The antagonistic APLs can inhibit the function of limited T-cell populations, and thus they could be potentially useful as antigen-specific therapy for autoimmune diseases in which $T$ cells play a pathogenic role. Indeed, APLs have been proven effective in the suppression of several autoimmune models. In an arthritis model, previous studies identified type II collagen $\mathrm{Cll}_{245-270}$ as a prominent T-cell epitope in collagen-induced arthritis in DBA/1 mice, and found that co-immunization with the analog peptide (I260A, A261B(hydroxyproline), F263N), also known as A9, significantly suppressed the disease $[22,23]$. As reported previously, however, the type II collagen residues Cll 260 (I) and Cll 263 (F) are I-Aq (MHC class II of $\mathrm{DBA} / 1$ mice) binding sites, and $\mathrm{A} 9$ was confirmed not to bind
I-Aq molecules [24,25]. The analog peptide A9 therefore seems to differ from conventional APLs, and the inhibitory effect and the mechanisms of conventional APLs on arthritis remain to be defined.

Several models of arthritis have so far been described and analyzed to understand the etiological mechanisms of RA. GPI-induced arthritis, a murine model of RA, is induced by immunization of DBA/1 mice with recombinant human GPI (rhGPI) [26]. We demonstrated previously that the Th17 subset of CD4+ T cells played a central role in the pathogenesis of GPI-induced arthritis; GPI-specific CD4+ ${ }^{+}$cells were skewed to $T_{H^{-17}}$ at the time of onset, and blockade of IL-17 resulted in a significant amelioration of arthritis [7]. We have also demonstrated that the major epitope of CD4+ $\mathrm{T}$ cells in GPI-induced arthritis was $\mathrm{hGPI}_{325-339}$, and immunization with the peptide induced severe polyarthritis (GPI peptide-induced arthritis) [27].

The present work is an extension to the above studies. Specifically, we explored the antigen-specific Th17 inhibition, explored the effects of APLs on arthritis, and investigated the inhibitory mechanisms of APLs, using the T-cell-dependent model of GPI peptide-induced arthritis. The results showed that many $\mathrm{hGPI}_{325-339}$-specific $\mathrm{CD} 4{ }^{+} \mathrm{T}$ cells employed $\mathrm{V} \beta 8.1$ 8.2 as the TCR repertoire, and co-immunization with APL (N329S, N329T, G332A, or G332V) significantly inhibited the development of arthritis. Our analysis of the inhibitory mechanisms of APLs indicates that our APLs can function as TCR antagonists; however, they can differentiate naïve $\mathrm{CD} 4^{+} \mathrm{T}$ cells to Th17 cells, but not Th2 cells or regulatory $T$ cells. Based on these findings, we define a new aspect for APLs, and propose that they may provide the basis for the invention of new antigen-specific therapy.

\section{Materials and methods \\ Mice}

DBA/1 mice were purchased from Charles River Laboratories, Yokohama, Japan. All mice were kept under specific pathogen-free conditions, and all experiments were conducted in accordance with the institutional ethical guidelines.

\section{Glucose-6-phosphate isomerase and synthetic peptides} The rhGPI and recombinant mouse GPI were prepared as described previously $[28,29]$. Briefly, human or mouse GPI cDNA was inserted into the plasmid pGEX-4T3 (Pharmacia, Uppsala, Sweden) for expression of glutathione-S-transferasetagged proteins. E. coli harboring pGEX-hGPI plasmid was allowed to proliferate at $37^{\circ} \mathrm{C}$, before the addition of $0.1 \mathrm{mM}$ isopropyl- $\beta$-d-thiogalactopyranoside to the medium, followed by further culture overnight at $30^{\circ} \mathrm{C}$. The bacteria were lysed with a sonicator and the supernatant was purified with a glutathione-sepharose column (Pharmacia). The purity was estimated by SDS-PAGE. 
Peptides for screening were synthesized with $70 \%$ purity by Wako Pure Chemical Industries, Ltd (Osaka, Japan), and peptides of a major peptide and antagonistic altered peptide ligands were synthesized with $90 \%$ purity by Invitrogen (Carlsbad, CA, USA). OVA O223-з39 peptide was purchased from AnaSpec (San Jose, CA, USA).

\section{Induction of arthritis}

DBA/1 mice were immunized with $10 \mu \mathrm{g}$ synthetic peptides for GPI peptide-induced arthritis in complete Freund's adjuvant (Difco Laboratories, Detroit, MI, USA), and in the indicated experiments $50 \mu \mathrm{g}$ altered peptide ligands were used with $10 \mu \mathrm{g} \mathrm{GPI}_{325-339}$ for co-immunization. The synthetic peptides were emulsified with complete Freund's adjuvant at a 1:1 ratio $(\mathrm{v} / \mathrm{v})$. For induction of arthritis, $150 \mu \mathrm{l}$ emulsion was injected intradermally at the base of the tail, and $200 \mathrm{ng}$ pertussis toxin was injected intraperitoneally on days 0 and 2 after immunization.

The arthritis score was evaluated visually using a score of 0 to 3 for each paw. A score of 0 represented no evidence of inflammation, 1 represented subtle inflammation or localized edema, 2 represented easily identified swelling that was localized to either the dorsal or ventral surface of the paws, and 3 represented swelling in all areas of the paws.

\section{Screening of antagonistic altered peptide ligands}

Mice were sacrificed on the indicated day. Spleens and draining lymph nodes (DLNs) were harvested, and splenocytes were hemolyzed with a solution of $0.83 \% \mathrm{NH}_{4} \mathrm{Cl}, 0.12 \%$ $\mathrm{NaHCO}_{3}$ and $0.004 \%$ EDTA ${ }_{2} \mathrm{Na}$ in PBS. Single-cell suspensions were prepared in RPMI 1640 medium (Sigma-Aldrich, St Louis, MO, USA) containing 10\% fetal bovine serum, 100 $\mathrm{U} / \mathrm{ml}$ penicillin, $100 \mu \mathrm{g} / \mathrm{ml}$ streptomycin and $50 \mu \mathrm{M} 2$-mercaptoethanol. CD4 ${ }^{+} \mathrm{T}$ cells from $\mathrm{DLNs}$ and $\mathrm{CD} 11 \mathrm{c}^{+}$dendritic cells from spleens were isolated by magenetic-activated cell sorting (Miltenyi Biotec, Bergisch Gladbach, Germany). The purity of the collected cells (>97\%) was confirmed by flow cytometry. CD11 $\mathrm{c}^{+}$dendritic cells treated with $50 \mu \mathrm{g} / \mathrm{ml}$ mitomycin $\mathrm{C}$ were used as antigen-presenting cells (APCs). The purified CD4+ T cells and APCs were co-cultured with $10 \mu \mathrm{M}$ synthetic peptide at a ratio of 1:3 in 96-well round-bottom plates (Nunc, Roskilde, Denmark) at $37^{\circ} \mathrm{C}$ under $5 \%$ carbon dioxide for 72 hours. The supernatants were assayed for IL-10 and IL-17 by the Quantikine ELISA kit (R\&D Systems, Minneapolis, MN, USA).

\section{Pre-pulse assay}

The pre-pulse assay was conducted as described previously [30]. Briefly, CD11 $\mathrm{c}^{+}$APCs from spleens $\left(4 \times 10^{4} /\right.$ well $)$ were cultured with a suboptimal concentration of $\mathrm{GPI}_{325-339}(3 \mu \mathrm{M})$ for 2 hours. In the meantime, native peptides were loaded onto APCs and presented on MHC. After 2 hours of incubation, APCs were washed twice to remove unbound peptides, and $30 \mu \mathrm{M}$ each antagonistic APL was added. After 18 hours of culture, CD4+ T cells $(2 \times 104 /$ well $)$ from DLNs were added, and after an additional 72 hours of culture the supernatants were assayed for IL-17 and IL-10 by ELISA. The inhibition ratio was calculated as follows:

1 - (IL-17 concentration in the presence of native peptides and APLs / IL-17 concentration in the presence of native peptides only) x $100(\%)$

\section{Flow cytometry}

Mice were sacrificed on the indicated day. The popliteal lymph nodes were harvested and single-cell suspensions were prepared as described above. Cells $\left(1 \times 10^{6} / \mathrm{ml}\right)$ were stimulated with $100 \mu \mathrm{g} / \mathrm{ml} \mathrm{rhGPI}$ in 96-well round-bottom plates (Nunc) for 24 hours and GoldiStop (BD PharMingen, San Diego, CA, USA) was added for the last 2 hours of each culture. Cells were first stained extracellularly, fixed and permeabilized with Cytofix/Cytoperm solution (BD PharMingen) and then stained intracellularly. Regulatory $T$ cells were stained with the Mouse Regulatory T cell Staining kit (eBioscience, San Diego, CA, USA) according to the protocol supplied by the manufacturer. For TCR repertoire screening, the Mouse TCR Screening Panel (BD PharMingen) was used. Samples were acquired on FACSCalibur (BD PharMingen) and data were analyzed with FlowJo (Tree Star, Ashland, OR, USA).

\section{Analysis of anti-glucose-6-phosphate isomerase antibody}

Sera were taken from immunized mice on day 28 and were diluted 1:500 (for $\lg$, $\operatorname{lgG}_{2 a}, \lg G_{2 b}$ and $\lg _{3}$ ) or 1:8,000 (for $\operatorname{lgG}_{1}$ ) in blocking solution (25\% Block Ace (Dainippon Sumitomo Pharma, Osaka, Japan) in PBS) for antibody analysis. We also prepared 96-well plates (Sumitomo Bakelite, Tokyo, Japan) coated with $5 \mu \mathrm{g} / \mathrm{ml}$ recombinant mouse GPI for 12 hours at $4^{\circ} \mathrm{C}$. After washing twice with a washing buffer (0.05\% Tween20 in PBS), the blocking solution was used for blocking nonspecific binding for 2 hours at room temperature. After two washes, $150 \mu$ diluted serum was added and incubated for 2 hours at room temperature. After three washes, alkaline phosphatase-conjugated anti-mouse lgG, horseradish peroxidase-conjugated anti-mouse $\lg _{1}, \lg _{2 a}, \lg _{2 b}$ (Zymed Laboratories, San Francisco, CA, USA) or $\operatorname{lgG}_{3}$ (Invitrogen) was added at a final dilution of 1:5,000 for 1 hour at room temperature. After three washes, color was developed with substrate solution (1 alkaline phosphatase tablet (Sigma-Aldrich) per $5 \mathrm{ml}$ alkaline phosphatase reaction solution (containing $9.6 \%$ diethanolamine and $0.25 \mathrm{mM} \mathrm{MgCl}_{2}, \mathrm{pH}$ 9.8)) or tetramethylbenzidine (KPL, Gaithersburg, MD, USA). Plates were incubated for 20 to 60 minutes at room temperature and the optical density was measured by a microplate reader at 405 $\mathrm{nm}$ (for $\lg G$ ) or at $450 \mathrm{~nm}$ (for $\lg _{1}, \lg G_{2 a}, \lg G_{2 b}$ and $\lg G_{3}$ ).

\section{Statistical analysis}

All data are expressed as the mean \pm standard error of the mean or standard deviation. Differences between groups were 
examined for statistical significance using the Mann-Whitney $U$ test. Differences of arthritis incidence between groups were examined using Fisher's exact test. $P<0.05$ denotes the presence of a statistically significant difference.

\section{Results \\ Designing and screening antagonistic altered peptide ligands}

We reported previously that the major T-cell epitope in GPIinduced arthritis is $\mathrm{hGPI}_{325-339}$, and immunization with the peptide provokes symmetrical polyarthritis (GPI peptideinduced arthritis) [28]. To investigate the effects of APLs in GPI peptide-induced arthritis, we first designed APLs of $\mathrm{hGPI}_{325-339}$. Since the $\mathrm{MHC}$ binding sites of $\mathrm{hGPI}_{325-339}$ exist at P1 (I328), P4 (F331), and P7 (E334) (IWYINCFGCETHAML) $[25,28]$, the amino acid residues of the TCR contact sites at P0 (Y327), P2 (N329), P3 (C330), P5 (G332), P6 (C333), and P8 (T335) were substituted for another peptide to design 20 types of APLs (Table 1).
To select antagonistic APLs, CD4+ T cells primed with rhGPI and APCs were co-cultured with each APL. The IL-1 7 production was markedly lower with APL 2, APL 5, APL 6, APL 7, APL 9, APL 10, APL 11, APL 12, APL 13, and APL 18 than with $\mathrm{hGPI}_{325-339}$, and therefore these APLs were considered candidates of antagonistic APLs (Figure 1a). None of the APLs induced IL-4 and IL-10 production (data not shown). We next explored the potency of the APLs in inhibiting IL-17 production in the presence of $\mathrm{hGPI}_{325-339}$. In the pre-pulse assay, APL 6 (N329S), APL 7 (N329T), APL 12 (G332A), and APL 13 (G332V) significantly reduced $\mathrm{IL}-17$ production by $\mathrm{CD} 4^{+} \mathrm{T}$ cells primed with rhGPI in the presence of $\mathrm{hGPI}_{325-339}(P<$ 0.01) (Figure 1b). We therefore considered these four APLs as antagonistic APLs.

\section{Inhibition of arthritis by antagonistic altered peptideligands}

Since GPI peptide-induced arthritis is mediated by Th17 and antagonistic APLs can suppress IL-17 production, we explored the efficacy of the prepared APLs on the inhibition of

Table 1

hGPI $_{325--339}$-derived altered peptide ligands used in the present study

\begin{tabular}{|c|c|c|c|c|c|c|c|c|c|c|c|c|c|c|c|}
\hline 325 to 339 & I & w & $Y$ & $\underline{1}$ & $\mathrm{~N}$ & C & $\underline{F}$ & G & C & $\underline{E}$ & $\mathbf{T}$ & $\mathbf{H}$ & A & M & $\mathbf{L}$ \\
\hline APL 1 & -- & -- & $\mathrm{N}$ & & -- & -- & -- & -- & -- & -- & -- & -- & -- & -- & -- \\
\hline APL 2 & -- & -- & Q & & -- & -- & -- & -- & -- & -- & -- & -- & -- & -- & -- \\
\hline APL 3 & -- & -- & $S$ & & -- & -- & -- & -- & -- & -- & -- & -- & -- & -- & -- \\
\hline APL 4 & -- & -- & $\mathrm{T}$ & & -- & -- & -- & -- & -- & -- & -- & -- & -- & -- & -- \\
\hline APL 5 & -- & -- & -- & & Q & -- & & -- & -- & & -- & -- & -- & -- & -- \\
\hline APL 6 & -- & -- & -- & & $S$ & -- & & -- & -- & & -- & -- & -- & -- & -- \\
\hline APL 7 & -- & -- & -- & & $\mathrm{T}$ & -- & & -- & -- & & -- & -- & -- & -- & -- \\
\hline APL 8 & -- & -- & -- & & -- & $\mathrm{N}$ & & -- & -- & & -- & -- & -- & -- & -- \\
\hline APL 9 & -- & -- & -- & & -- & Q & & -- & -- & & -- & -- & -- & -- & -- \\
\hline APL 10 & -- & -- & -- & & -- & $S$ & & -- & -- & & -- & -- & -- & -- & -- \\
\hline APL 11 & -- & -- & -- & & -- & $\mathrm{T}$ & & -- & -- & & -- & -- & -- & -- & -- \\
\hline APL 12 & -- & -- & -- & & -- & -- & & A & -- & & -- & -- & -- & -- & -- \\
\hline APL 13 & -- & -- & -- & & -- & -- & & V & -- & & -- & -- & -- & -- & -- \\
\hline APL 14 & -- & -- & -- & & -- & -- & & -- & $\mathrm{N}$ & & -- & -- & -- & -- & -- \\
\hline APL 15 & -- & -- & -- & & -- & -- & & -- & Q & & -- & -- & -- & -- & -- \\
\hline APL 16 & -- & -- & -- & & -- & -- & & -- & $S$ & & -- & -- & -- & -- & -- \\
\hline APL 17 & -- & -- & -- & & -- & -- & & -- & $\mathrm{T}$ & & -- & -- & -- & -- & -- \\
\hline APL 18 & -- & -- & -- & & -- & -- & & -- & -- & & $\mathrm{N}$ & -- & -- & -- & -- \\
\hline APL 19 & -- & -- & -- & & -- & -- & & -- & -- & & Q & -- & -- & -- & -- \\
\hline APL 20 & -- & -- & -- & & -- & -- & & -- & -- & & $S$ & -- & -- & -- & -- \\
\hline
\end{tabular}

The MHC binding sites exist at glucose-6-phosphate isomerase (GPI) 328 (I), GPI 331 (F) and GPI 334 (E) as indicated (underlined). The amino acid residues of the T-cell receptor contact sites at P0 (Y327), P2 (N329), P3 (C330), P5 (G332), P6 (C333), and P8 (T335) were substituted for the indicated peptides to design 20 types of altered peptide ligands (APLs). 

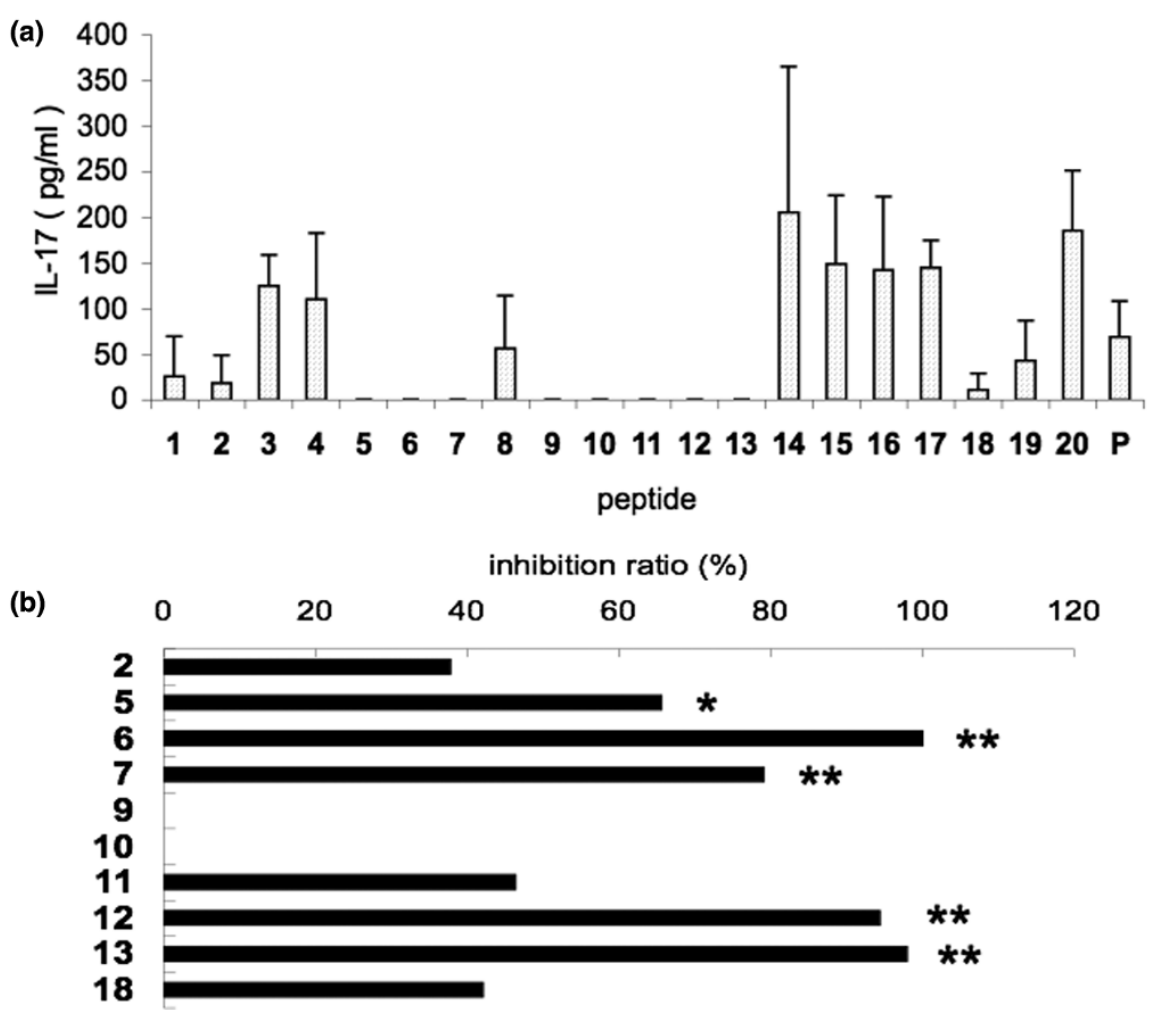

Altered peptide ligands markedly suppress IL-17 production by glucose-6-phosphate isomerase-primed CD4+ T cells. Altered peptide ligand (APL) 6, APL 7, APL 9, APL 12 and APL 13 markedly suppress IL-17 production by glucose-6-phosphate isomerase (GPI)-primed CD4+T cells. Mice were sacrificed on day 8 after immunization. CD4 + T cells were purified from draining lymph node cells of recombinant human GPI (hGPI)-immunized DBA/1 mice, and CD11 $\mathrm{c}^{+}$antigen-presenting cells (APCs) were purified from spleen cells. (a) CD4+ T cells primed with hGPI and APCs were cocultured with $10 \mu \mathrm{M}$ synthetic peptide for 72 hours. The supernatants were assayed for IL-17 by ELISA. P, positive control (hGPI ${ }_{325-339}$ ). (b) CD11 $\mathrm{c}^{+}$APCs were cultured with a suboptimal concentration $\mathrm{GPI}_{325-339}(3 \mu \mathrm{M})$ for 2 hours, washed twice to remove unbound peptides, and 30 $\mu \mathrm{M}$ each antagonistic APL was added. After 18 hours of culture, CD4+ T cells $\left(2 \times 10^{4} /\right.$ well) were added, and after an additional 72 hours of culture, the supernatants were assayed for IL-17 by ELISA. The inhibition ratio was calculated as stated in Pre-pulse assay. Data presented as average \pm standard deviation of three culture wells. ${ }^{\star} P<0.05,{ }^{\star \star} P<0.01$ (Mann--Whitney $\mathrm{U}$ test). Representative data of two independent experiments.

arthritis. First, we immunized DBA/1 mice with each APL alone, and confirmed that no overt arthritis developed (data not shown). DBA/1 mice were then co-immunized with $\mathrm{hGPI}_{325-339}$ and each APL to explore the development of arthritis. Mice co-immunized with APL 6, APL 12 and APL 13 developed significantly attenuated arthritis after day 12 , and those co-immunized with APL 7 after day 16, compared with mice immunized with $\mathrm{hGPI}_{325-339}$ alone $(P<0.05)$ (Figure 2, upper panel). Co-immunization with APL 13 also significantly suppressed the incidence of arthritis $(P<0.05)$ (Table 2). Coimmunization with $\mathrm{hGPI}_{325-339}$ and APL 15, an agonistic APL, however, did not affect the severity or course of arthritis (Figure 2, middle panel). Moreover, mice co-immunized with $\mathrm{hGPI}_{325-339}$ and $\mathrm{OVA}_{323-339}$ also had a similar course of arthritis to $\mathrm{hGPI}_{325-339}$ alone (Figure 2, lower panel).

\section{Identification of TCRV $\beta$ usage of $h$ GPI $_{325-339}$-specificTh17 cells}

To investigate the inhibitory mechanisms of the antagonistic APLs, we explored TCRV $\beta$ usage of $\mathrm{hGPI}_{325-339}$-specific
$\mathrm{CD}^{+}{ }^{+} \mathrm{T}$ cells. The CD4 $+\mathrm{T}$ cells primed with $\mathrm{hGPI}{ }_{325-339}$ were stimulated with $\mathrm{hGPI}_{325-339}$ in vitro and the $\mathrm{TCRV} \beta$ repertoire was analyzed by flow cytometry and compared with that before stimulation. Stimulation with $\mathrm{hGPI}_{325-339}$ expanded the population of CD4 ${ }^{+} \mathrm{T}$ cells with TCRV $\beta 8.1$ 8.2 (Figure 3a). We also found that much of IL-17 was produced by CD4+ T cells with TCRV $\beta 8.18 .2$ following stimulation with $\mathrm{hGPI}_{325-339}$ (Figure 3b). These data indicate that many hGPI ${ }_{325-339}$-specific Th17 cells use TCRV $\beta 8.1$ 8.2.

\section{Effect of antagonistic altered peptide ligands on differentiation of Th17 and regulatory T cells}

In vitro analysis showed that the antagonistic APLs suppressed IL-17 production, and that co-immunization with the APLs inhibited the development of arthritis. We therefore explored the effect of APLs on Th17 differentiation. Our previous report suggested that cross-reactivity of $\mathrm{CD}^{+} \mathrm{T}$ cells primed with $\mathrm{hGPI}_{325-339}$ to $\mathrm{mGPI}_{325-339}$ was critical for the development of arthritis. We therefore assessed the population of $\mathrm{mGPI}_{325-339}$ reactive Th17 cells in the DLNs of mice co- 

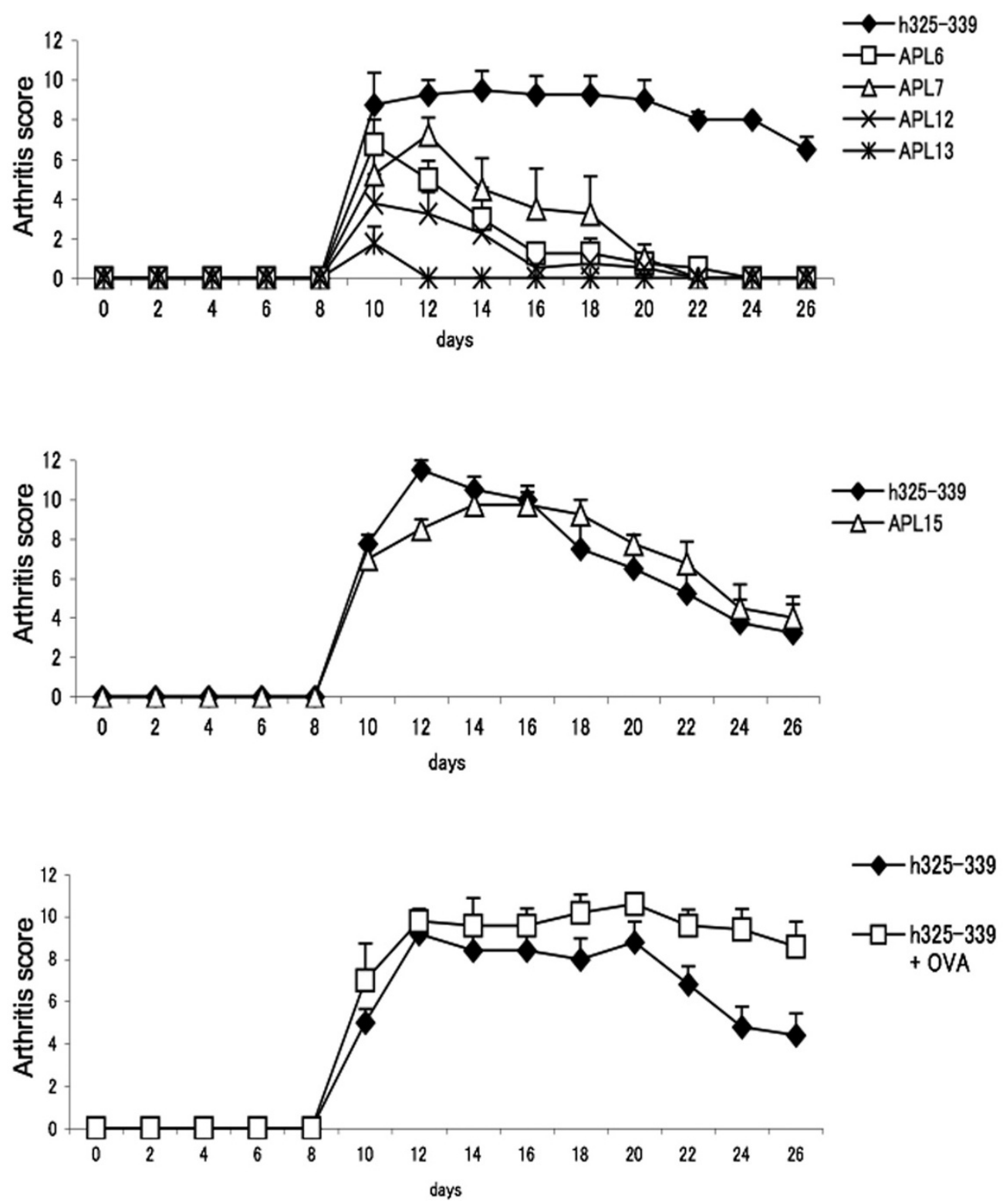

Co-immunization with antagonistic altered peptide ligands suppresses the development of arthritis. Mice were co-immunized with antagonistic altered peptide ligand (APL) 6, APL 7, APL 12, APL 13 (upper panel), the agonistic APL 15 (middle panel) or OVA peptide (lower panel). Progression of arthritis was significantly suppressed in mice co-immunized with APL 6, APL 12 and APL 13 after day 12, and in mice co-immunized with APL 7 after day $16(P<0.05$, Mann--Whitney $U$ test). Data presented as mean arthritis score ( \pm standard error of the mean) of four mice in one representative experiment of at least two independent experiments.

immunized with each APL. IL-17 production by CD4+ $\mathrm{T}$ cells with TCRV $\beta 8.18 .2$ or other TCRV $\beta$ with stimulation of $\mathrm{mGPI}_{325-339}$ was not affected by co-immunization with APLs (Figure $4 \mathrm{a}$ ), and neither was affected IL-17 production with $\mathrm{hGPI}_{325-339}$ (data not shown). Unexpectedly, IL-17 production was considerable with stimulation of the corresponding APLs (Figure 4b). ELISA showed undetectable levels of IL-4, and the IL-10 production, and IFN $\gamma$ production was not affected (data not shown). Co-immunization with APLs did neither affect the population of regulatory $T$ cells nor the expression of CD25 (Figure 5), and stimulation of DLN cells of co-immunized mice with APLs in vitro did not induce the expansion of regulatory $\mathrm{T}$ cells (data not shown).

Identification of TCRV $\beta$ usage of altered peptide ligandspecific CD4+ $\mathbf{T}$ cells

The unexpected data mentioned above suggested that APLspecific CD4+T cells were developed by co-immunization. We 
Table 2

\begin{tabular}{llll}
\hline \multicolumn{2}{l}{ Effects of co-immunization with altered peptide ligands on the development of arthritis } & \\
\hline Co-immunization & Incidence & Day of onset & Maximum severity \\
\hline None & $8 / 8$ & $10 \pm 0.0$ & $10.9 \pm 1.4$ \\
APL 6 & $8 / 8$ & $10 \pm 0.0$ & $7.5 \pm 2.0^{\star}$ \\
APL 7 & $6 / 8$ & $10 \pm 0.0$ & $7.8 \pm 1.7^{\star}$ \\
APL 12 & $7 / 8$ & $10.3 \pm 0.8$ & $5.0 \pm 1.2^{\star \star}$ \\
APL 13 & $3 / 8 \dagger$ & $10 \pm 0.0$ & $4.0 \pm 0.0^{\star \star}$ \\
\hline
\end{tabular}

Mice were co-immunized with $10 \mu \mathrm{g}$ glucose-6-phosphate isomerase $\mathrm{hGPI}_{325-339}$ and $50 \mu \mathrm{g}$ indicated antigen. Data presented as incidence or mean \pm standard deviation. ${ }^{\dagger} P<0.05$ (Fisher's exact test). ${ }^{\star} P<0.005,{ }^{\star \star} P<0.001$ (Mann--Whitney $\mathrm{U}$ test).

therefore investigated TCRV $\beta$ usage of APL-specific CD4+ T cells. The CD4 ${ }^{+} \mathrm{T}$ cells primed with each APL were stimulated with the corresponding APL in vitro and the TCRV $\beta$ repertoire was analyzed by flow cytometry and compared with that before stimulation. Stimulation with APL 6, APL 7 and APL 12 induced expansion of the population of $\mathrm{CD}^{+} \mathrm{T}$ cells with TCRV $\beta 8.1$ 8.2; however, this expansion was not so remarkable as that of $\mathrm{hGPI}_{325-339}$-specific CD4 ${ }^{+} \mathrm{T}$ cells (Figures $3 \mathrm{a}$ and 6). Interestingly, stimulation with APL 13 hardly induced the expansion of the population of $\mathrm{CD}^{+} \mathrm{T}$ cells with TCRV $\beta 8.18 .2$ (Figure 6) or any other specific $V \beta$ chain, although each APL stimulation could proliferate CD4+ T cells primed with the corresponding APL as efficiently as $h \mathrm{GPI}_{325}$ 339 (data not shown).

\section{Effects of antagonistic altered peptide ligands on anti- mouse glucose-6-phosphate isomerase antibody production}

Since administration of anti-CD4 monoclonal Abs with immunization prevents the development of arthritis and completely inhibits the production of anti-mGPI Abs in GPI-induced arthritis, $\mathrm{mGPI}$ is considered a thymus-dependent antigen to the humoral immune response [26]. We therefore next investigated the effects of APLs on antibody production. Co-immunization with APL 6, APL 7, APL 12 and APL 13 significantly suppressed the titers of anti-mGPI Abs $(P<0.01, P<0.005$, $P<0.001$ and $P<0.001$, respectively) (Figure 7). We also investigated the anti-mGPI lgG isotype. Co-immunization with APL 7, APL 12 and APL 13 significantly suppressed the titer of anti-mGPI $\operatorname{lgG}_{1}$ isotype $(P<0.005, P<0.001$ and $P<$ 0.01 , respectively). Any other anti-mGPI lgG isotype was hardly detected, however, and any bias to specific isotype was not found as an effect of APL.

\section{Discussion}

APLs are considered useful for antigen-specific therapy of autoimmune diseases and allergy. Treatments with APLs have so far been tested in several autoimmune models, and especially experimental autoimmune encephalitis has been enthusiastically examined for APLs designed as a single amino acid substitution of a TCR contact site. In experimental autoimmune encephalitis in Lewis rats, co-immunization with the APL (K91A) of myelin basic protein $\mathrm{MBP}_{87-99}$ strongly inhibited the development of the disease by suppression of IFN $\gamma$ and TNF $\alpha$, not T-cell proliferation [31]. Furthermore, another study of experimental autoimmune encephalitis in SJL mice showed that co-immunization with the APL (W144Q) of myelin proteolipid protein PLP $_{139-151}$ also inhibited the disease, and that the T-cell clone specific for the APL (W144Q) possessed the Th0 or Th2 phenotype [32].

Although one study used conventional APLs in collageninduced arthritis [33], unconventional APLs with substitutions at MHC binding sites were mainly tested in arthritis models. Myers and colleagues reported that the analog peptide (I260A, A261B(hydroxyproline), F263N) significantly suppressed collagen-induced arthritis by inducing Th2 cells in DBA/1 mice [34]. They also reported the suppression of collagen-induced arthritis in HLA-DR1 and HLA-DR4 transgenic mice using other analog peptides with substitutions at $\mathrm{MHC}$ binding sites $[35,36]$. Another group reported also that the antigen-specific proinflammatory response to the human cartilage glycoprotein-39 (263 to 275) epitope was suppressed in DR4 transgenic mice by APLs with substitution at MHC binding sites [37].

In our study, we designed various APLs (N329S, N329T, G332A, or G332V) of $\mathrm{hGPI}_{325-339}$ with substitutions at TCR contact sites, and showed that co-immunization with the individual APL significantly inhibited the development of arthritis. Although the APLs had antagonism to Th17 primed with hGPI cells in vitro (Figure 1), analysis of the mechanisms of the effect of co-immunizing APLs showed normal development of hGPI- ${ }_{325-339}$-specific Th17 cells and APL-specific Th17 cells in vivo (Figure 4). Co-immunization with $\mathrm{hGPI}_{325-339}$ and the APL might have induced both hGPI- ${ }_{325-339}$-specific Th17 clones and APL-specific Th17 clones by the adjuvant effects of complete Freund's adjuvant and pertussis toxin.

Since both the TCR signal and the co-stimulatory signal are essential for priming of naïve $T$ cells, our data suggested the potency of the APLs as agonists to some TCRs. It is likely that 
Figure 3

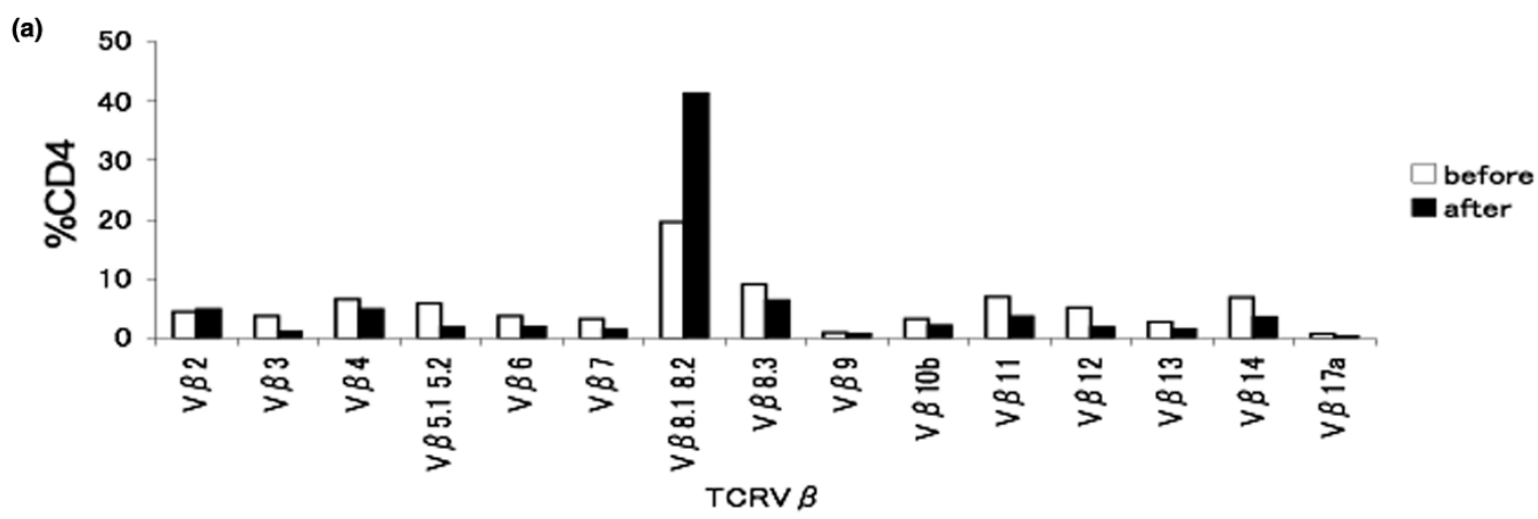

(b)
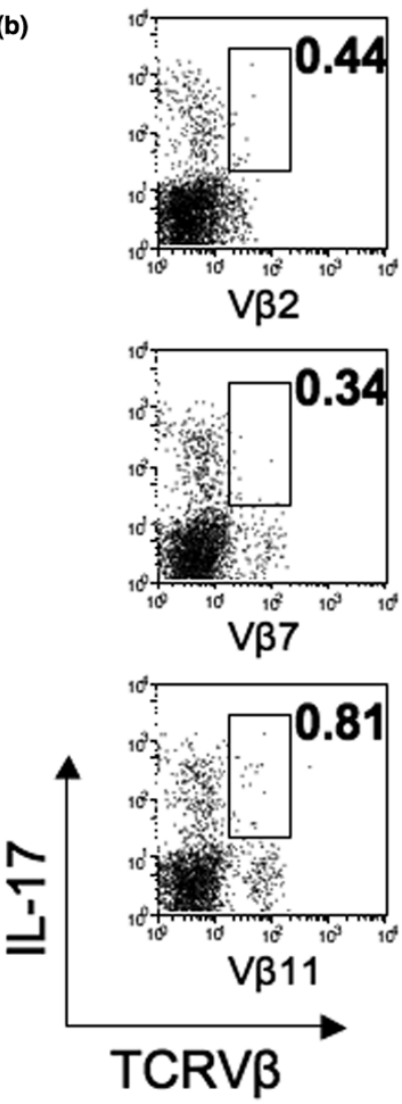
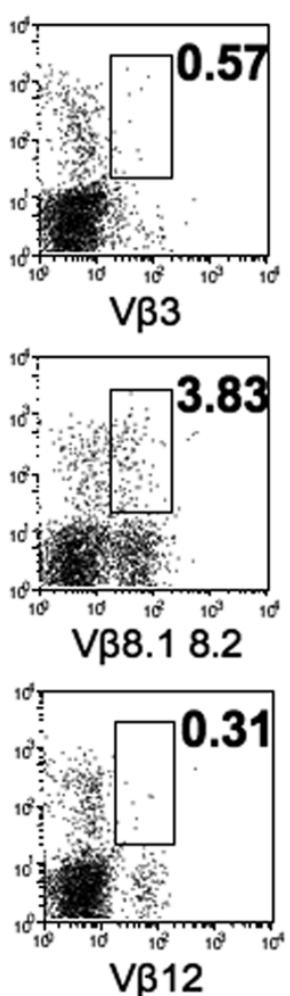

Vß12

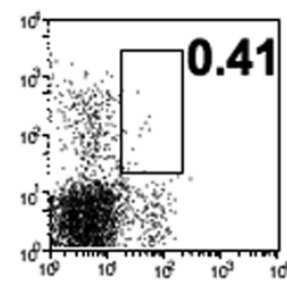

VB4
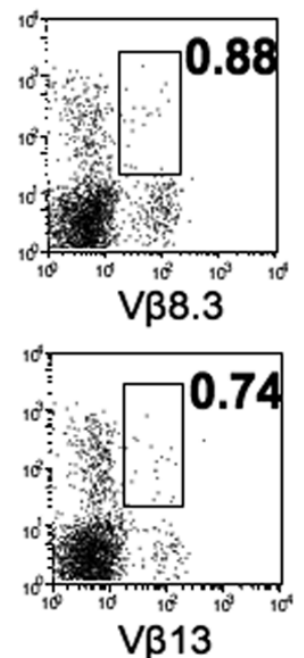

V $\beta 13$
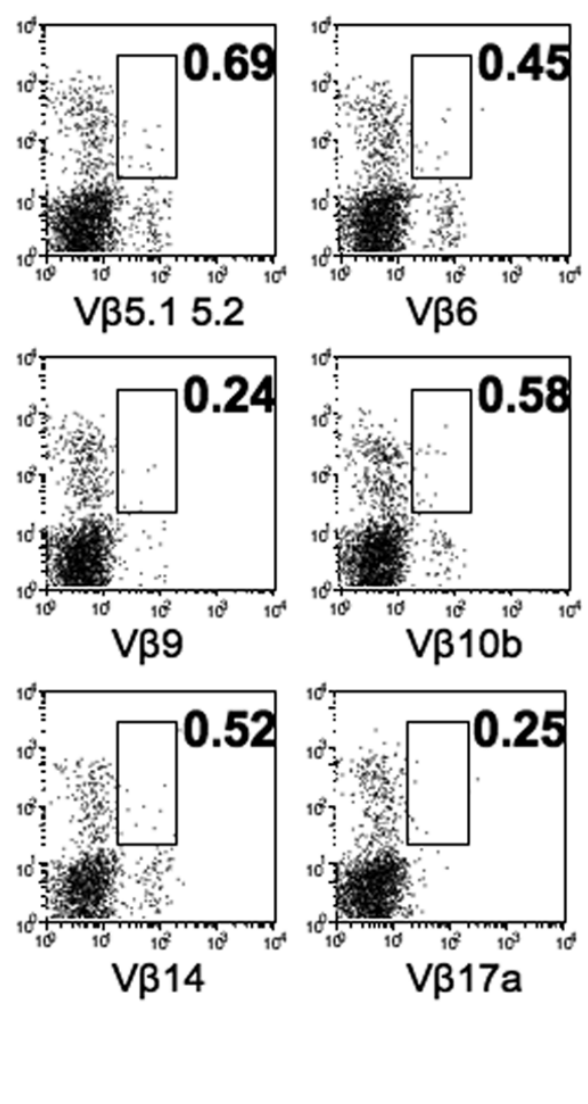

Human glucose-6-phosphate isomerase-specific Th17 cells use TCRV $\beta 8.1$ 8.2. Many glucose-6-phosphate isomerase hGPI ${ }_{325-339}$-specific Th17 cells use TCRV $\beta 8.1$ 8.2. Mice were immunized with $10 \mu \mathrm{g} \mathrm{hGP}_{325-339}$, and draining lymph node cells on day 6 were stimulated with $20 \mu \mathrm{M}$ $\mathrm{hGPI}_{325-339}$ in vitro. (a) Ratios of TCRV $\beta$ repertoire to CD4+ $\mathrm{T}$ cells. The TCRV $\beta$ repertoire of CD4+ $\mathrm{T}$ cells was analyzed by flow cytometry: before stimulation with hGPI ${ }_{325-339}$ in vitro for 72 hours, and after stimulation. (b) GoldiStop was added in the last 4 hours of the 24-hour culture. Flow cytometry analysis for IL-17 was gated in CD4high cells. Representative data of two independent experiments.

an antigen acts as an agonist to one T-cell clone and as an antagonist to another T-cell clone because any TCR can cross-react with various antigens. Although the antigen specificity is mainly determined by the complementary determining regions, the different ratio of TCRV $\beta$ usage between $\mathrm{hGPI}_{325}$ ${ }_{339}$-specific CD4 $^{+} \mathrm{T}$ cells and APL-specific CD4 ${ }^{+} \mathrm{T}$ cells (especially APL 13) indicates that each CD4+ $\mathrm{T}$ cell is a differ- ent clone that leads to different antigen specificity, and does not cross-react to the APLs and hGPI ${ }_{325-339}$ to conduct positive TCR signals, respectively. Our previous paper showed that $\mathrm{T}$ cells primed with $\mathrm{hGPI}_{325-339}$ could cross-react to $\mathrm{mGPI}_{325-339}$ and that the cross-reactivity to $\mathrm{mGPI}_{325-339}$ was crucial for induction arthritis [27]. The findings that immunization with the APLs (APL 6, APL 7, APL 12, APL 13) alone 
(a)
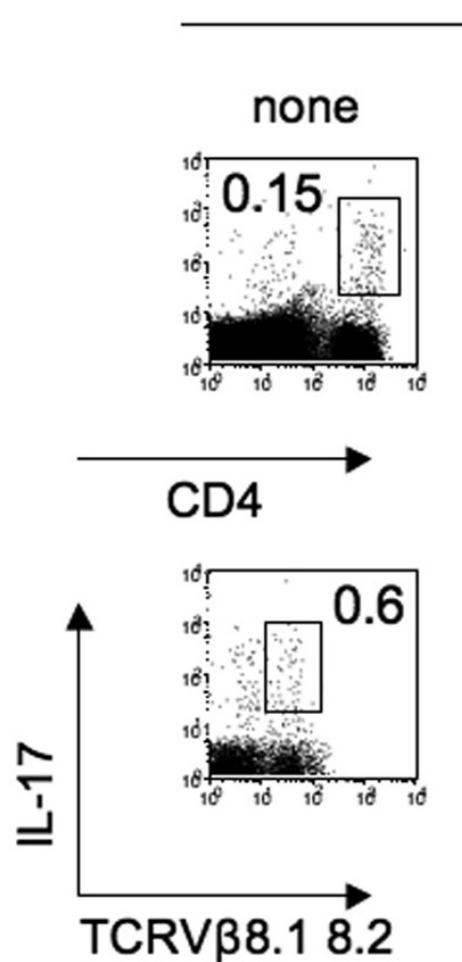

(b)
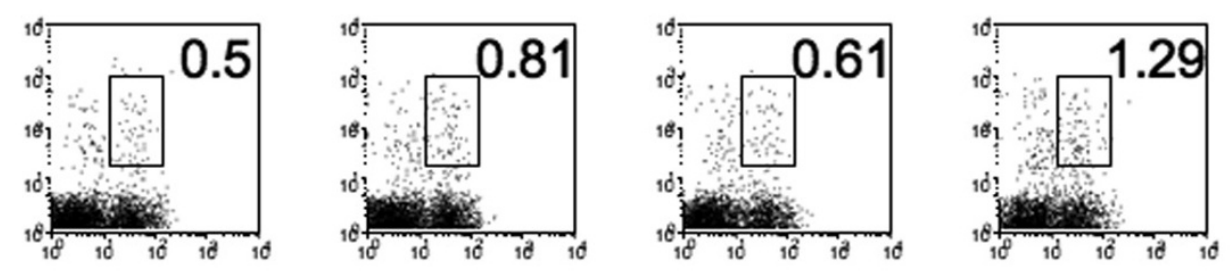

APL 13
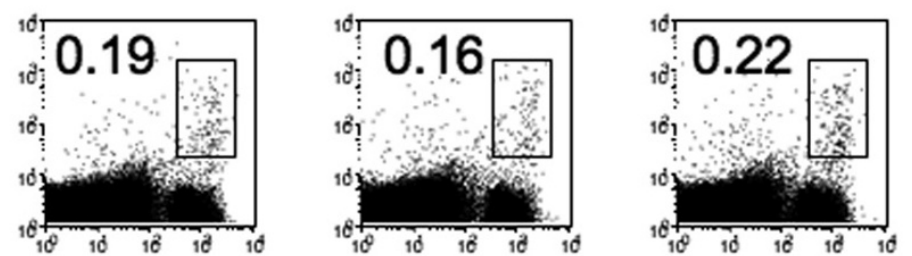

APL 6

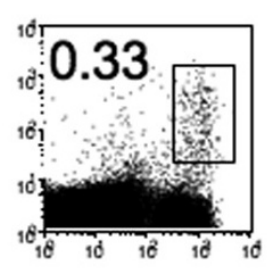

\section{CD4}

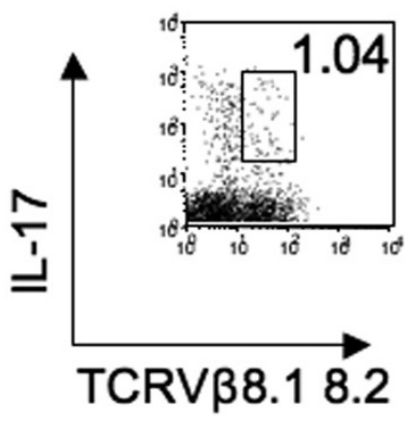

APL 7
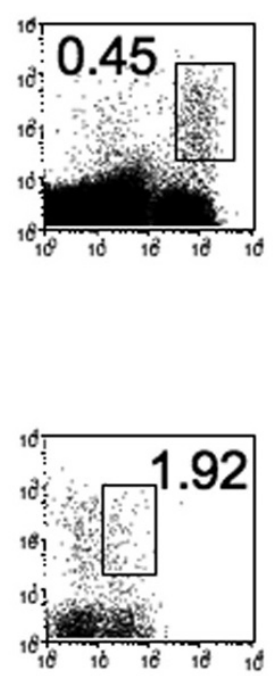

APL 12
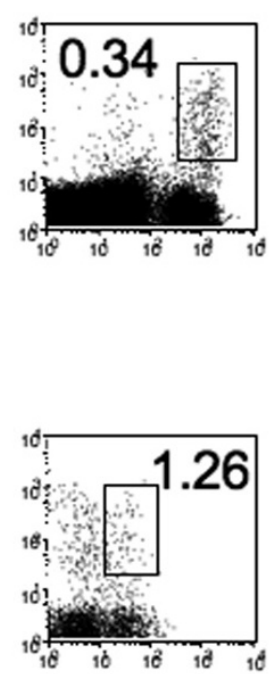

APL 13

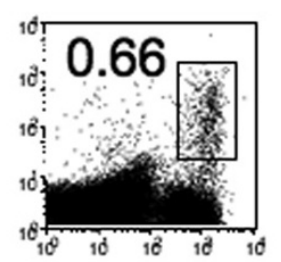

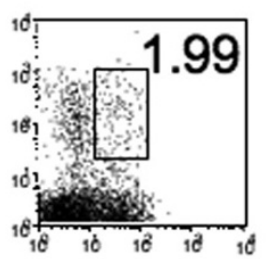

Co-immunization with altered peptide ligands does not affect IL-17 production. Mice were immunized with $10 \mu \mathrm{g}$ glucose-6-phosphate isomerase $\mathrm{hGPI}_{325-339}$ and $50 \mu \mathrm{g}$ each altered peptide ligand (APL). Draining lymph node cells on day 6 were stimulated for 24 hours in vitro (a) with $10 \mu \mathrm{M}$ mouse $\mathrm{GPI}_{325-339}$ or (b) with $10 \mu \mathrm{M}$ corresponding APL. GoldiStop was added in the last 4 hours of each culture. Flow cytometry analysis for IL-17 and TCRV $\beta$ repertoire was gated in CD4high cells. None, immunization with no APL (hGPI ${ }_{325-339}$ alone). Representative flow cytometry data of two independent experiments. 


\section{coimmunization}

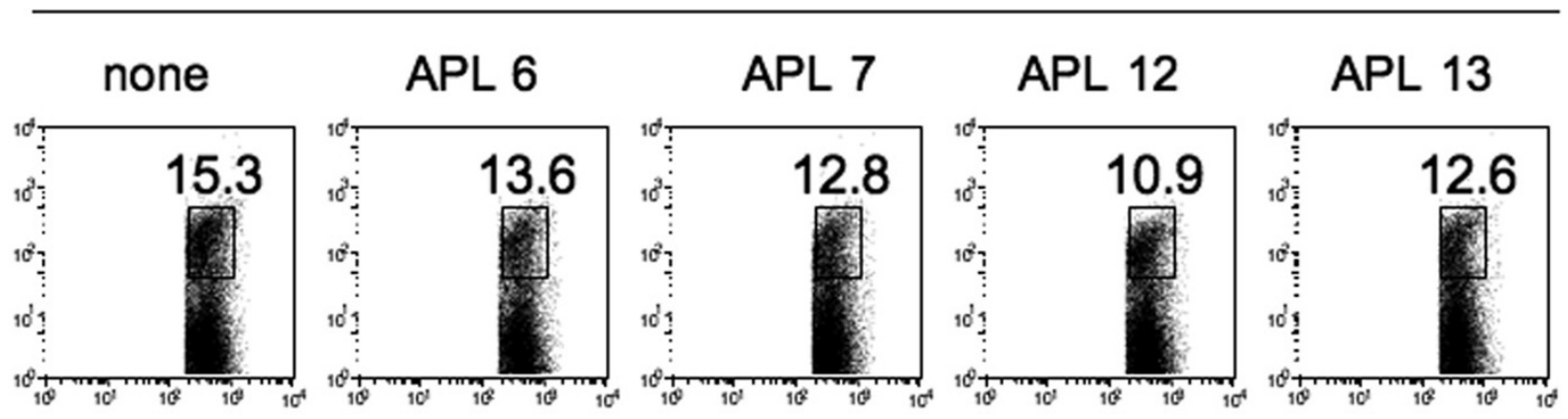

\section{CD4}
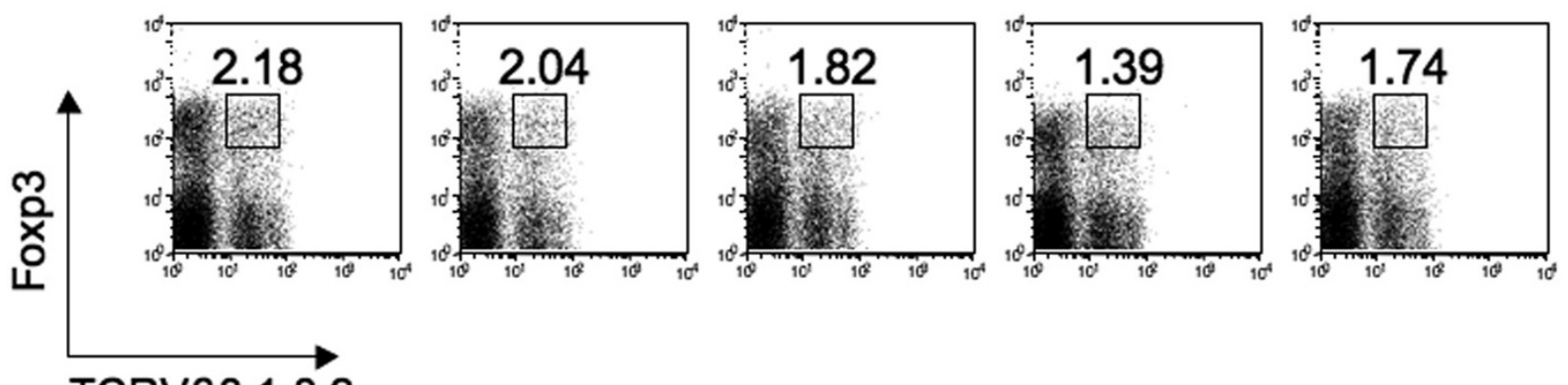

TCRV $\beta 8.18 .2$
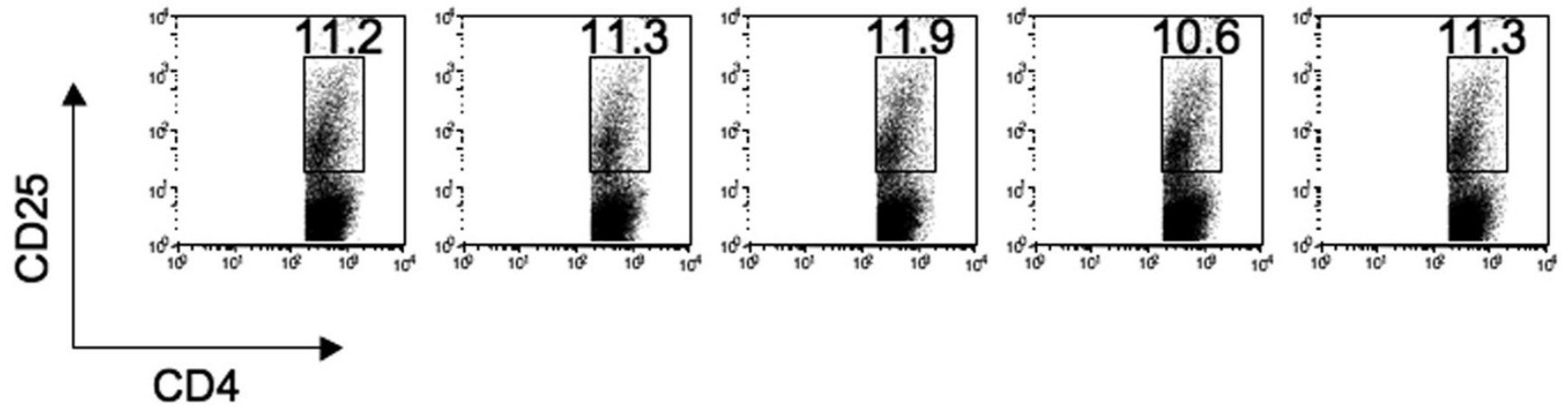

Co-immunization with altered peptide ligands neither induces regulatory T cells nor modulates CD25 expression. Mice were immunized with $10 \mu \mathrm{g}$ glucose-6-phosphate isomerase hGPI ${ }_{325--339}$ and $50 \mu \mathrm{g}$ each altered peptide ligand (APL), and draining lymph node cells on day 6 were stained with Foxp3 and CD25. Flow cytometry analysis was gated in CD4+ cells. None, immunization with no APL (hGPI ${ }_{325-339}$ alone). Representative flow cytometry data of two independent experiments.

could not induce any overt arthritis indicated that APL-specific $T$ cells could not cross-react $\mathrm{mGPI}_{325-339}$ suggesting they do not have potential for induction of arthritis.

One of the inhibitory mechanisms of APL is anergy. Allen and colleagues reported that APL could induce anergy of T-cell clones by partial activation [38], which was characterized by an increase in cell volume and upregulation of CD25, without cytokine production or cell proliferation. Another mechanism is induction of anti-inflammatory T-cell lineages such as Th2/Th0 as well as regulatory $\mathrm{T}$ cells. Nicholson and colleagues reported that co-immunization with $\mathrm{PLP}_{139-151}$ and $\mathrm{APL}$ (W144L/H147R) did not inhibit the induction of PLP ${ }_{139-151^{-}}$ specific T cells, but induced APL-specific Th2/Th0 phenotype cells to suppress the progression of experimental autoimmune encephalitis by stander suppression [39]. 


\section{APL 6}

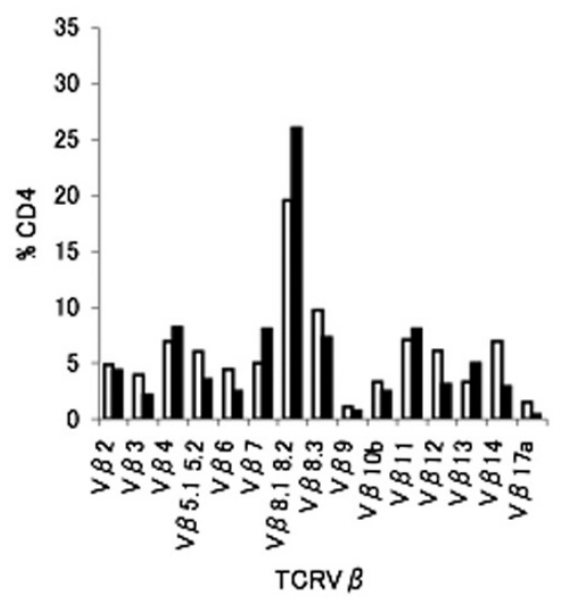

APL 12

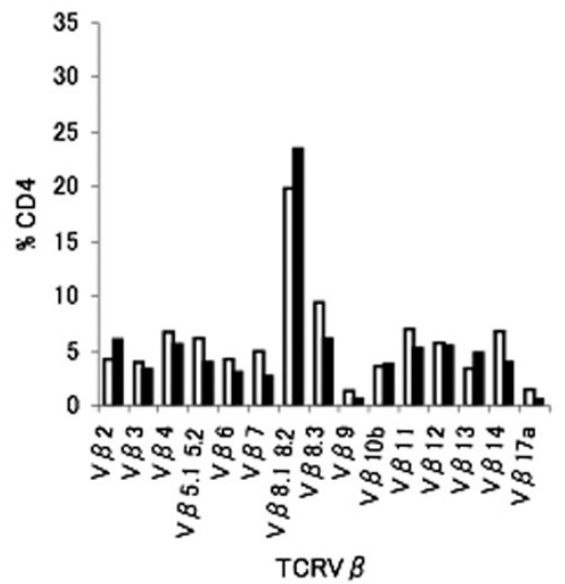

APL 7

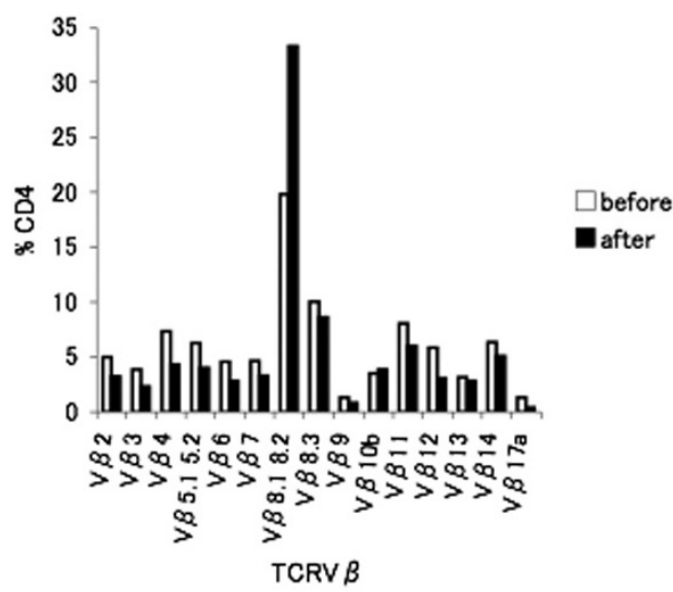

APL 13

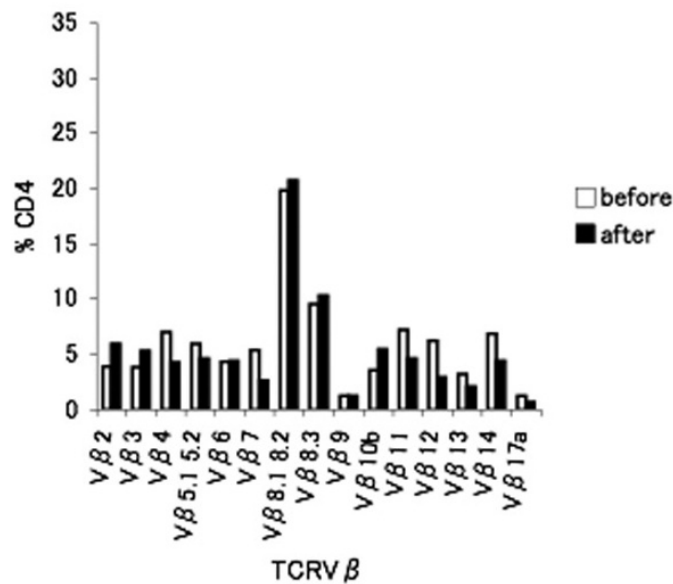

TCRV $\beta$ usage of altered peptide ligand-specific CD $4^{+} T$ cells. TCRV $\beta$ usage of altered peptide ligand (APL)-specific CD $4^{+} T$ cells was not remarkably shifted to TCRV $\beta 8.1$ 8.2. Mice were immunized with $10 \mu \mathrm{g}$ each APL, and draining lymph node cells on days 7 to 9 were stimulated with $20 \mu \mathrm{M}$ corresponding APL in vitro. Ratios of TCRV $\beta$ repertoire to CD4 ${ }^{+} \mathrm{T}$ cells. The TCRV $\beta$ repertoire of $C D 4^{+} \mathrm{T}$ cells was analyzed by flow cytometry: before stimulation with the corresponding in vitro for 72 hours, and after stimulation.

In our system, however, neither of these mechanisms was likely because the APLs did not inhibit IL-17 production and cell proliferation with stimulation of $\mathrm{mGPI}_{325-339}$, and induction of any anti-inflammatory and regulatory $\mathrm{T}$ cells was not detected. Nevertheless, it is probable that APLs inhibit $\mathrm{mGPI}_{325-339}$-specific T cells because our analysis showed significant reductions of anti-mGPI Abs, which were Abs to thymus-dependent antigen [26]. We assumed that competitive bindings of APL to TCR in vivo were likely in our system; however, it cannot be denied that amino acid substitutions in peptides, even those that are not directly involved in $\mathrm{MHC}$ binding, might affect the overall structure of the peptide and biding affinity to MHC. Taken together, competitive binding of the APLs to $\mathrm{hGPI}_{325-339}$-specific TCR or $\mathrm{MHC}$ in vivo is considered most likely as an inhibitory mechanism of APLs in our system.

The major interest in APLs is their clinical application; several studies showed that APLs suppress autoreactive cells in RA and Sjogren's syndrome $[40,41]$. Although clinical trials of APL in RA have not yet been conducted, phase II clinical trials in multiple sclerosis have been reported $[42,43]$. In one study 

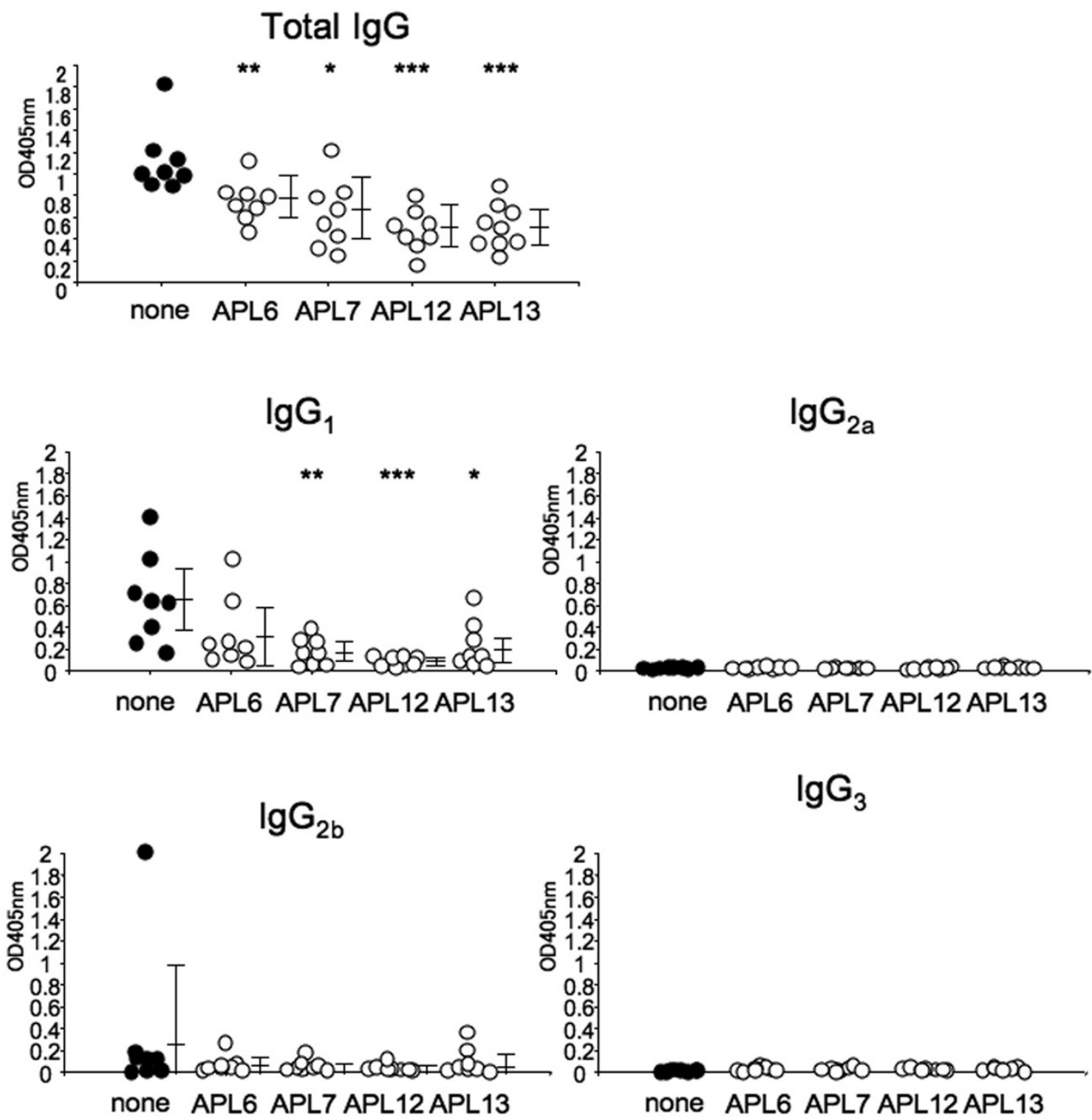

Co-immunization with altered peptide ligands suppresses production of antibodies to mouse glucose-6-phosphate isomerase. Sera were taken on day 28 from mice co-immunized with $10 \mu \mathrm{g}$ glucose-6-phosphate isomerase $\mathrm{hGPI}_{325--339}$ and $50 \mu \mathrm{g}$ each altered peptide ligand (APL), and the titers of anti-mouse GPI IgG and IgG isotype were analyzed by ELISA. Each symbol represents a single mouse. Data presented as mean optimal density \pm standard deviation. ${ }^{*} P<0.01,{ }^{\star \star} P<0.005,{ }^{* \star *} P<0.001$ (Mann--Whitney U test).

of eight patients with multiple sclerosis, subcutaneous administration at $50 \mathrm{mg}$ dose once-weekly of CGP77116 - an APL with substitutions at multiple TCR contact sites of $\mathrm{MBP}_{83-99}$ resulted in the development of exacerbations in two patients with enhancement of $\mathrm{MBP}_{83-99}$-reactive Th1 response [42]. Another double-blind placebo-controlled clinical trial included 142 patients who received various doses of subcutaneously injected NBI5788, an APL of $\mathrm{MBP}_{83-99}$ with substitutions at TCR contact sites [43]. In contrast to the former study, the administration of $5 \mathrm{mg}$ APL weekly significantly decreased inflammatory lesions in the central nervous system. Unfortu- nately, the study was halted because $9 \%$ of the patients developed hypersensitivity reactions, but none discontinued at a dose of $5 \mathrm{mg}$ in the double-blind phase whereas all patients discontinued in the double-blind phase after receiving higher doses of 20 or $50 \mathrm{mg}$. Low-dose APLs might therefore be useful agents for antigen-specific therapies of autoimmune diseases including RA, and their efficacy in RA might be more promising than in multiple sclerosis because drugs can be injected directly into the inflammatory lesions. 
Finally, can GPI be a target of antigen-specific therapies in RA? It has been reported that patients with severe forms of RA retained high titers of anti-GPI Abs [44-47] and GPI-reactive CD4 ${ }^{+} \mathrm{T}$ cells were detected among anti-GPI-Ab-positive patients with RA [48]. These findings highlight autoimmune responses to GPI are occurring in some patients with RA, and GPI can be a target of antigen-specific therapies to them although further studies are needed to clarify the exact pathological role of GPI in RA.

\section{Conclusions}

The results of the present study showed that APLs with substitutions at TCR contact sites inhibit GPI peptide-induced arthritis. Novel antigen-specific therapies based on APLs may prove beneficial in arthritis induced by autoimmune responses to autoantigens.

\section{Competing interests}

The authors declare that they have no competing interests.

\section{Authors' contributions}

$\mathrm{KI}$ wrote the manuscript and conducted all experiments. $\mathrm{YY}$, $\mathrm{Al}, \mathrm{YK}, \mathrm{KY}$ YT, and RM assisted in the completion of the experiments. TS designed and coordinated the study. IM coordinated and directed the study. YN designed the APLs and provided advice for the study. TH, DG and SI participated in the discussion.

\section{Acknowledgements}

The present work was supported in part by a grant from The Japanese Ministry of Science and Culture (IM, TS).

\section{References}

1. Struyk L, Hawes GE, Chatila MK, Breedveld FC, Kurnick JT, Elsen PJ van den: $T$ cell receptors in rheumatoid arthritis. Arthritis Rheum 1995, 38:577-589.

2. Kremer JM, Westhovens R, Leon M, Di Giorgio E, Alten R, Steinfeld S, Russell A, Dougados M, Emery P, Nuamah IF, Williams GR, Becker JC, Hagerty DT, Moreland LW: Treatment of rheumatoid arthritis by selective inhibition of T-cell activation with fusion protein CTLA4Ig. N Engl J Med 2003, 349:1907-1915.

3. Genovese MC, Becker JC, Schiff M, Luggen M, Sherrer Y, Kremer J, Birbara C, Box J, Natarajan K, Nuamah I, Li T, Aranda R, Hagerty DT, Dougados M: Abatacept for rheumatoid arthritis refractory to tumor necrosis factor $\alpha$ inhibition. N Engl J Med 2005, 353:1114-1123.

4. Yocum DE, Furst DE, Kaine JL, Baldassare AR, Stevenson JT, Borton MA, Mengle-Gaw LJ, Schwartz BD, Wisemandle W, Mekki QA, Tacrolimus Rheumatoid Arthritis Study Group: Efficacy and safety of tacrolimus in patients with rheumatoid arthritis: a double-blind trial. Arthritis Rheum 2003, 48:3328-3337.

5. Doodes PD, Cao Y, Hamel KM, Wang Y, Farkas B, Iwakura $Y$, Finnegan A: Development of proteoglycan-induced arthritis is independent of IL-17. J Immuno/ 2008, 181:329-337.

6. Nakae S, Nambu A, Sudo K, Iwakura Y: Suppression of immune induction of collagen-induced arthritis in IL-17-deficient mice. $\mathrm{J}$ Immunol 2003, 171:6173-6177.

7. Iwanami K, Matsumoto I, Tanaka-Watanabe $Y$, Mihara M, Ohsugi $Y$, Mamura M, Goto D, Ito S, Tsutsumi A, Kishimoto T, Sumida T: Crucial role of IL-6/IL-17 axis in the induction of arthritis by glucose-6-phosphate isomerase. Arthritis Rheum 2008, 58:754-763.

8. Koenders Ml, Lubberts $E$, Oppers-Walgreen $B$, Bersselaar $L$ van den, Helsen MM, Di Padova FE, Boots AMH, Gram H, Joosten
$L A B$, Berg WB van den: Blocking of interleukin-17 during reactivation of experimental arthritis prevents joint inflammation and bone erosion by decreasing RANKL and interleukin-1. Am J Pathol 2005, 167:141-149.

9. Nakae S, Saijo S, Horai R, Sudo K, Mori S, Iwakura Y: IL-17 production from activated $T$ cells is required for the spontaneous development of destructive arthritis in mice deficient in IL-1 receptor antagonist. Proc Natl Acad Sci USA 2003, 100:5986-5990.

10. Hirota $K$, Hashimoto $M$, Yoshitomi H, Tanaka $S$, Nomura $T$, Yamaguchi T, Iwakura Y, Sakaguchi N, Sakaguchi S: T cell selfreactivity forms a cytokine milieu for spontaneous development of IL-17+ Th cells that cause autoimmune arthritis. J Exp Med 2007, 204:41-47.

11. Ye P, Garvey PB, Zhang P, Nelson S, Bagby G, Summer WR, Schwarzenberger $P$, Shellito JE, Kolls JK: Interleukin-17 and lung host defense against Klebsiella pneumoniae infection. $\mathrm{Am} J$ Respir Cell Mol Biol 2001, 25:335-340.

12. Wu Q, Martin RJ, Rino JG, Breed R, Torres RM, Chu HW: IL-13dependent IL-17 production is essential in neutrophil recruitment and activity in mouse lung defense against respiratory Mycoplasma pneumoniae infection. Microbes Infect 2007, 9:78-86.

13. Rudner XL, Happel KI, Young EA, Shellito JE: Interleukin-23 (IL23)-IL-17 cytokine axis in murine Pneumocystis carinii infection. Infect Immun 2007, 75:3055-3061.

14. Conti HR, Shen F, Nayyar N, Stocum E, Sun JN, Lindemann MJ, Ho AW, Hai JH, Yu JJ, Jung JW, Filler SG, Masso-Welch P, Edgerton M, Gaffen SL: Th17 cells and IL-17 receptor signaling are essential for mucosal host defense against oral candidiasis. J Exp Med 2009, 206:299-311.

15. Shibata $\mathrm{K}$, Yamada H, Hara H, Kishihara $\mathrm{K}$, Yoshikai $\mathrm{Y}$ : Resident $\mathbf{V} \delta 1+\gamma \delta \mathrm{T}$ cells control early infiltration of neutrophils after Escherichia coli infection via IL-17 production. J Immunol 2007, 178:4466-4472.

16. Maini R, St Clair EW, Breedveld F, Furst D, Kalden J, Weisman M, Smolen J, Emery P, Hariiman G, Feldmann M, Lipsky P: Infliximab (chimeric anti-tumour necrosis factor alpha monoclonal antibody) versus placebo in rheumatoid arthritis patients receiving concomitant methotrexate: a randomized phase III trial. ATTRACT Study Group. Lancet 1999, 354:1932-1939.

17. Lipsky PE, Heijde DM van der, St Clair EW, Furst DE, Breedveld FC, Kalden JR, Smolen JS, Weisman M, Emery P, Feldmann M, Harriman GR, Maini RN, Anti-Tumor Necrosis Factor Trial in Rheumatoid Arthritis with Concomitant Therapy Study Group: Infliximab and methotrexate in the treatment of rheumatoid arthritis. Anti-Tumor Necrosis Factor Trial in Rheumatoid Arthritis with Concomitant Therapy Study Group. N Engl J Med 2000, 343:1594-1602.

18. Choy EH, Isenberg DA, Garrood $T$, Farrow $S$, loannou $Y$, Bird $H$, Cheung N, Williams B, Hazleman B, Price R, Yoshizaki K, Nishimoto N, Kishimoto T, Panayi GS: Therapeutic benefit of blocking interleukin- 6 activity with an anti-interleukin- 6 receptor monoclonal antibody in rheumatoid arthritis: a randomized, doubleblind, placebo-controlled, dose-escalation trial. Arthritis Rheum 2002, 46:3143-3150.

19. Nishimoto N, Yoshizaki K, Miyasaka N, Yamamoto K, Kawai S, Takeuchi T, Hashimoto J, Azuma J, Kishimoto T: Treatment of rheumatoid arthritis with humanized anti-interleukin- 6 receptor antibody: a multicenter, double-blind, placebo-controlled trial. Arthritis Rheum 2004, 50:1761-1769.

20. Sloan-Lancaster J, Allen PM: Altered peptide ligand-induced partial T cell activation: molecular mechanisms and role in $\mathrm{T}$ cell biology. Annu Rev Immunol 1996, 14:1-27.

21. Chen $Y Z$, Matsushita $S$, Nishimura $Y$ : Response of a human $T$ cell clone to a large panel of altered peptide ligands carrying single residue substitutions in an antigenic peptide. $J$ Immunol 1996, 157:3783-3790.

22. Brand DD, Myers LK, Terato K, Whittington KB, Stuart JM, Kang $\mathrm{AH}$, Rosloniec EF: Characterization of the T cell determinants in the induction of autoimmune arthritis by bovine $\alpha 1$ (II)-CB11 in H-2a mice. J Immunol 1994, 152:3088-3097.

23. Myers LK, Rosloniec EF, Seyer JM, Stuart JM, Kang AH: A synthetic peptide analogue of a determinant of type II collagen prevents the onset of collagen-induced arthritis. I Immunol 1993, 150:4652-4658. 
24. Rosloniec EF, Whittington KB, Brand DD, Myers LK, Stuart JM: Identification of MHC class II and TCR binding residues in the type II collagen immunodominant determinant mediating collagen-induced arthritis. Cell Immunol 1996, 172:21-28.

25. Bayrak Ş, Holmdahl R, Travers P, Lauster R, Hesse M, Dölling R, Mitchison NA: T cell response of I-Aq mice to self type II collagen: meshing of the binding motif of the I-Aq molecule with repetitive sequences results in autoreactivity to multiple epitopes. Int Immunol 1997, 9:1687-1699.

26. Schubert D, Maier B, Morawietz L, Krenn V, Kamradt T: Immunization with glucose-6-phosphate isomerase induces $T$ celldependent peripheral polyarthritis in generally unaltered mice. J Immuno/ 2004, 172:4503-4509.

27. Iwanami K, Matsumoto I, Tanaka Y, Goto D, Ito S, Tsutsumi A, Sumida T: Arthritogenic T cell epitope in glucose-6-phosphate isomerase-induced arthritis. Arthritis Res Ther 2008, 10:R130.

28. Matsumoto I, Lee DM, Goldbach-Mansky R, Sumida T, Hitchon CA, Schur PH, Anderson RJ, Coblyn JS, Weinblatt ME, Brenner M, Duclos B, Pasquali JL, El-Gabalawy H, Mathis D, Benoist C: Low prevalence of antibodies to glucose-6-phosphate isomerase in patients with rheumatoid arthritis and a spectrum of other chronic autoimmune disorders. Arthritis Rheum 2003, 48:944-954.

29. Matsumoto I, Staub A, Benoist C, Mathis D: Arthritis provoked by linked $\mathbf{T}$ and $\mathrm{B}$ recognition of a glycolytic enzyme. Science 1999, 286:1732-1735.

30. De Magistris MT, Alexander J, Coggeshall M, Altman A, Gaeta FCA, Grey HM, Sette A: Antigen analog-major histocompatibility complexes act as antagonists of the $\mathrm{T}$ cell receptor. Cell 1992, 68:625-634.

31. Karin BN, Mitchell DJ, Brocke S, Ling N, Steinman L: Reversal of experimental autoimmune encephalomyelitis by a soluble peptide variant of a myelin basic protein epitope: T cell receptor antagonism and reduction of interferon $\gamma$ and tumor necrosis factor $\alpha$ production. J Exp Med 1994, 180:2227-2237.

32. Micholson LB, Greer JM, Sobel RA, Lees MB, Kuchroo VJ: An altered peptide ligand mediates immune deviation and prevents autoimmune encephalomyelitis. Immunity 1995, 3:397-405

33. Wakamatsu E, Matsumoto I, Yoshiga Y, Hayashi T, Goto D, Ito S, Sumida T: Altered peptide ligands regulate type II collageninduced arthritis in mice. Mod Rheumato/ 2009, 19:366-371.

34. Myers LK, Tang B, Rosloniec EF, Stuart JM, Chiang TM, Kang AH: Characterization of a peptide analog of a determinant of type II collagen that suppresses collagen-induced arthritis. J Immunol 1998, 161:3589-3595.

35. Myers LK, Sakurai Y, Tang B, He X, Rosloniec EF, Stuart JM, Kang $\mathrm{AH}$ : Peptide-induced suppression of collagen-induced arthritis in HLA-DR1 transgenic mice. Arthritis Rheum 2002, 46:3369-3377.

36. Sakurai Y, Brand DD, Tang B, Rosloniec EF, Stuart JM, Kang AH, Myers LK: Analog peptides of type II collagen can suppress arthritis in HLA-DR4 (DRB1*0401) transgenic mice. Arthritis Res Ther 2006, 8:R150.

37. Boots $A M H$, Huberts $H$, Kouwijzer M, den Hoed-van Zandbrink L, Westrek-Esselink BM, van Doorn C, Stenger R, Bos ES, van Lierop MC, Verheijden GF, Timmers CM, van Staveren CJ: Identification of an altered peptide ligand based on the endogenously presented, rheumatoid arthritis-associated, human cartilage glycoprotein-39 (263-275) epitope: an MHC anchor variant peptide for immune modulation. Arthritis Res Ther 2007, 9:R71.

38. Sloan-Lancaster J, Evavold BD, Allen PM: Induction of T-cell anergy by altered T-cell-receptor ligand on live antigen-presenting cells. Nature 1993, 363:156-159.

39. Nicholson LB, Murtaza A, Hafler BP, Sette A, Kuchroo VJ: A T cell receptor antagonist peptide induces $T$ cells that mediate bystander suppression and prevent autoimmune encephalomyelitis induced with multiple myelin antigens. Proc Natl Acad Sci USA 1997, 94:9279-9284

40. Ohnishi Y, Tsutsumi A, Matsumoto I, Goto D, Ito S, Kuwana M, Uemura Y, Nishimura Y, Sumida T: Altered peptide ligand control type II collagen-reactive $T$ cells from rheumatoid arthritis patients. Mod Rheumato/ 2006, 16:226-228.

41. Naito $Y$, Matsumoto I, Wakamatsu E, Goto D, Ito S, Tsutsumi A, Sumida T: Altered peptide ligands regulate muscarinic acetyl- choline receptor reactive T cells of patients with Sjogren's syndrome. Ann Rheum Dis 2006, 65:269-271.

42. Bielekova B, Goodwin B, Richert N, Cortese I, Kondo T, Afshar G, Gran B, Eaton J, Antel J, Frank JA, McFarland HF, Martin R: Encephalitogenic potential of the myelin basic protein peptide (amino acids 83-99) in multiple sclerosis: Results of a phase II clinical trial with an altered peptide ligand. Nat Med 2000, 6:1167-1175.

43. Kappos L, Comi G, Panitch H, Oger J, Antel J, Conlon P, Steinman L, The Altered Peptide Ligand in Relapsing MS Study Group: Induction of a non-encephalitogenic type $2 \mathrm{~T}$ helper-cell autoimmune response in multiple sclerosis after administration of an altered peptide ligand in a placebo-controlled, randomized phase II trial. Nat Med 2000, 6:1176-1182.

44. Matsumoto I, Lee DM, Goldbach-Mansky R, Sumida T, Hitchon $\mathrm{CA}$, Schur PH, Anderson RJ, Coblyn JS, Weinblatt ME, Brenner M, Duclos B, Pasquali JL, El-Gabalawy H, Mathis D, Benoist C: Low prevalence of antibodies to glucose-6-phosphate isomerase in patients with rheumatoid arthritis and a spectrum of other chronic autoimmune disorders. Arthritis Rheum 2003, 48:944-954.

45. Kassahn $D$, Kolb $C$, Solomon $\mathrm{S}$, Bochtler $\mathrm{P}$, Illges $\mathrm{H}$ : Few human autoimmune sera detect GPI. Nat Immuno/ 2002, 3:411-412.

46. Schubert D, Schmidt M, Zaiss D, Jungblut PR, Kamradt T: Autoantibodies to GPI and creatine kinase in RA. Nat Immuno/ 2002, 3:411.

47. Van Gaalen FA, Toes RE, Ditzel HJ, Schaller M, Breedveld FC, Verweij CL, Huizinga TW: Association of autoantibodies to glucose-6-phosphate isomerase with extraarticular complications in rheumatoid arthritis. Arthritis Rheum 2004 50:395-399.

48. Kori $\mathrm{Y}$, Matsumoto I, Zhang $\mathrm{H}$, Yasukochi $\mathrm{T}$, Hayashi $\mathrm{T}$, Iwanami $\mathrm{K}$, Goto D, Ito S, Tsutsumi A, Sumida T: Characterisation of Th1/ Th2 type, glucose-6-phosphate isomerase reactive $T$ cells in the generation of rheumatoid arthritis. Ann Rheum Dis 2006 , 65:968-969. 